\title{
Characteristics of headache and its relationship with disease severity in patients with Crimean-Congo hemorrhagic fever
}

\author{
Kırım Kongo Kanamalı Ateşinde gözlenen baş ağrısının özellikleri ve hastalık şiddetiyle ilişkisi
}

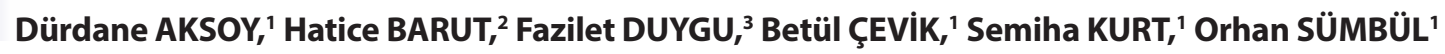

\begin{abstract}
Summary
Objectives: Crimean-Congo Hemorrhagic Fever (CCHF) is a fatal, tick-borne disease. The classic clinical presentation of CCHF is characterized by sudden onset of high fever, chills, and severe headache. There are no previous reports on the characteristics of headaches caused by CCHF. Therefore, we investigated the relationship between CCHF-induced headache and the clinical course of the disease.

Methods: We included 60 patients with headache diagnosed with CCHF; they were divided into two groups: group 1 included patients with hospital stay $<7$ days and group 2 included patients with hospital stay $>7$ days. The control group included 43 viral pneumonia patients with headache. Patients described the characteristics of headaches and also self-rated the severity with a numeric pain scale that classified headache as either mild or severe.

Results: In the group with $\mathrm{CCHF}, 66.7 \%$ of the reported headaches met criteria for diagnosis of migraine. This ratio was significantly higher than that in the control group (37.5\%). The headache severity scores in group 1 were lower than those in group 2. The hospitalization length was shorter $(p=0.004)$ and the platelet levels were higher in CCHF patients with mild headache compared with CCHF patients with severe headache $(\mathrm{p}=0.005)$.

Conclusion: CCHF patients had more often and severe headaches than the controls. The severity of headache may be associated with the severity of vascular endothelial damage, vasodilatation, and abnormal release of inflammatory cytokines in CCHF similar in migraine. Most CCHF patients experienced migraine-like headaches, suggesting that cerebral vessel involvement might be important in both CCHF and migraine.
\end{abstract}

Keywords: Crimean-Congo hemorrhagic fever; headache; migraine.

\begin{abstract}
Özet
Amaç: Kırım-Kongo kanamalı ateşi (KKKA), Kırım-Kongo kanamalı ateşi virüsünün etken olduğu, kenelerle bulaşan, fatal seyredebilen bir hastalıktır. Hastalığın erken belirtileri yüksek ateş, halsizlik, ciddi baş ağrısıdır. KKKA' da sık görülen baş ağrısıyla ilişkili herhangi bir araştırma yoktur. Bu çalışmada KKKA hastalarında gözlenen baş ağrısının özelliklerini ve klinik tablonun şiddetiyle ilişkisini araştırdık.

Gereç ve Yöntem: Çalışmaya hastanemizde KKKA tanısıyla yatan baş ağrılı 60 hasta alındı, yatış sürelerine göre: 7 günden kısa yatanlar "grup 1", 7 gün ve daha uzun yatanlar "grup 2" şeklinde tanımlandı. Kontrol grubu aynı klinikten baş ağrısı olan yüksek ateşli 43 viral pnömoni hastası idi. KKKA hastalarına baş ağrısıyla ilgili sayısal ağrı skalası anketi uygulandı, sonuca göre hastalar "hafif-ağrılı grup" ve "şiddetli-ağrılı grup" olarak ikiye ayrıldı. Tüm hastalara baş ağrılarının özellikleriyle ilgili ayrıntılar sorularak 'Baş ağrısı sınıflandırma derneğinin' kriterlerine göre migren özelliklerini taşıyıp taşımadığı araştıııldı.

Bulgular: KKKA hastalarının \% 66.7' sinin ağrısı migren kriterlerine uymakta idi. Bu oran kontrol grubu oranından (\%37.5) anlamlı şekilde yüksekti. KKKA hastalarında: Grup 1' deki hastaların baş ağrısı skorları grup 2' den anlamlı şekilde daha düşüktü. Hafif-ağrılı grubun yatış süresi şiddetli-ağrılı gruba göre daha kısaydı $(p=0.004)$ ve Platelet değerleri daha yüksekti $(p=0.005)$.

Sonuç: KKKA hastalarında baş ağrısı kontrol grubuna göre daha sık, şiddetliydi ve migrenöz özellikler taşıyordu. Migrende vasküler endotelyal disfonksiyon, vasodilatasyon ve inflamatuar mediatörler sorumlu tutulmaktadır. KKKA' da virusun yaptığı serebral vasküler endotelyal hasar, salgılanan proinflamatuar sitokinler hastalarda migrendekine benzeyen baş ağrılarını tetikliyor gibi görünmektedir. KKKA hastalarında gözlenen migren-benzeri baş ağrısı, her iki hastalıkta serebral vasküler tutulumun ağrı etyopatogenezi açısından önemini vurgulamaktadır.
\end{abstract}

Anahtar sözcükler: Baş ağrısı; Kırım Kongo kanamalı ateşi; migren.

'Department of Neurology, Gaziosmanpaşa University Faculty of Medicine, Tokat, Turkey

${ }^{2}$ Department of Neurology, Tokat State Hospital, Tokat, Turkey

${ }^{3}$ Department of Infectious Diseases, Ankara Oncology Training and Research Hospital, Ankara, Turkey

Submitted (Başvuru tarihi) 27.01.2017 Accepted after revision (Düzeltme sonrası kabul tarihi) 21.08.2017 Available online date (Online yayımlanma tarihi) 26.01.2018

Correspondence: Dr. Dürdane Aksoy. Kaleardı Mah Muhittin Füsunoğlu Caddesi 60100, Tokat, Turkey.

Phone: +903562288104 e-mail: dbekar@yahoo.com

๑) 2018 Turkish Society of Algology 


\section{Introduction}

Crimean-Congo hemorrhagic fever (CCHF) is caused by a virus in the family Bunyaviridae and genus Nairovirus called the CCHF virus. CCHF is a fatal, tickborne zoonotic disease with mortality rates ranging from $3 \%$ to $80 \%$. To date, infections have been reported in the Balkans, Eastern Europe, Central Asia, Turkey, China, Africa, and the Middle East. ${ }^{[1-5]}$ Specifically in Turkey, CCHF poses a significant public health risk due to the high fatality associated with infection. ${ }^{[6-9]}$ Climate change, environmental destruction, and increases in global trade and travel have facilitated the spread of CCHF virus to locations where it had not been previously detected. There is no vaccine or cure for $\mathrm{CCHF}$, prompting multiple national health care organizations to recommend serious precautions in preventing infection. ${ }^{[10]}$

Infection commonly occurs when the CCHF virus is transmitted from the bite of the hyalomma tick, which tends to carry the most contagious strains. Contact with contaminated blood or blood-containing bodily fluids may also transmit this disease. ${ }^{[11,12]}$ If the virus is transmitted via a tick bite, the incubation period usually lasts 1-3 days, and if infection occurred via exposure to contaminated blood, the incubation period lasts 5-6 days. The burden of viral RNA is nearly identical among blood, saliva, and urine; however, nosocomial transmission between patients has been rarely reported. ${ }^{[2,3,10,13]}$ Prognosis depends on the extent of imbalance of coagulation factors and the severity of leucopenia and thrombocytopenia. ${ }^{[12,14,15]}$

Following the incubation period, clinical symptoms appear quickly, which include high fevers, chills, headaches, myalgias, and arthralgias. Patients do not commonly exhibit gastrointestinal symptoms such as nausea, vomiting, diarrhea, and dyspepsia. Several days following exposure to the virus, patients begin to hemorrhage such that petechiae and ecchymoses may be observed clinically. Blood can be detected in patients' sputum and stool, and severe hemorrhaging may result in hypovolemic shock. ${ }^{[15,16]}$

The classic clinical presentation of CCHF is characterized by a sudden onset of high fever, chills, and severe headache. ${ }^{[15-17]}$ There are no previous reports on the characteristics of headaches caused by CCHF virus; therefore, we investigated the quality, duration, and severity of CCHF-related headaches in patients to explore the relationship between the disease and headache characteristics.

\section{Material and Methods}

We evaluated 69 patients admitted to the Department of Infectious Diseases and Clinical Microbiology in Gaziosmanpasa University Medical Faculty with positive IgM and/or positive PCR results for CCHF virus; the control group included 93 hospitalized viral pneumonia patients with fever. The study was performed on patients experiencing headache during the course of their sickness. Following evaluation, 60 patients with CCHF and 43 with pneumonia were included. Exclusion criteria included any condition causing cognitive impairment such as Alzheimer's disease, stroke, Parkinson's disease, or any chronic neurological disease such as migraine or epilepsy. Written informed consent was obtained from each patient following a detailed explanation of the purpose of the study. Gaziosmanpasa University Ethics Committee approved the investigation design (13-KAEK-092), and all experiments were performed in accordance with the Declaration of Helsinki.

Each subject underwent thorough neurological examinations and numerous laboratory tests during hospitalization. The patients were asked to describe the most severe headache they had during the course of their illness. All patients self-rated their headache severity via a numeric pain scale with established reliability and validity. Total scores ranged from 1, indicating no pain, to 10 , indicating excruciating pain. ${ }^{[18]}$ Patients who rated their headache pain from 1 to 5 had mild headaches, whereas those who rated their headache pain from 6 to 10 had severe headaches. Patients also described the quality of their headaches by indicating whether they were unilateral, throbbing, and changed with physical activity. Associated symptoms were also documented such as photophobia, phonophobia, nausea, and vomiting to determine whether the headache could be classified as a migraine according to the International Headache Classification Committee. ${ }^{[19]}$ All neurological examinations and pain questionnaires were provided by a single neurologist. In addition to the length of hospital stay, laboratory tests including complete blood count, glucose, urea, creatinine, alanine aminotransferase (ALT), 
aspartate aminotransferase (AST), creatine kinase, and lactic dehydrogenase (LDH) levels were documented. CCHF patients were subdivided into two groups based on the length of hospital stay: group 1 included patients having hospital stay $<7$ days and group 2 included patients having hospital stay $>7$ days. Specifically, headache traits, mean length of hospital stay, and platelet levels were compared between these two groups. In addition, headache scores and characteristics of pains were compared among patients with CCHF and pneumonia.

\section{Statistical analysis}

Categorical variables were analyzed using Pearson's chi-square test. Fisher's exact test was used if the expected value was $<5$ in the $2 \times 2$ contingency tables. Categorical variables were expressed either as percentages (\%) or quantity (n). The KolmogorovSmirnov normality test was used to determine whether continuous variables were normally distributed. Continuous variables were expressed as the mean \pm standard deviation (SD). Independent samples t-test was used to compare two continuous variables. Correlations between headache severity and both platelet (PLT) levels and length of hospitalization were determined using the Spearman correlation test. The association between PLT levels and length of hospitalization was determined by calculating the Pearson's correlation coefficient. A p-value $<0.05$ was considered statistically significant. Data obtained from this study was analyzed using SPSS version 19.0 (IBM Statistical Package for Social Sciences Statistics version 19.0, SPSS Inc., IBM Co., Somers, NY).

\section{Results}

Although $87 \%$ of the CCHF patients experienced headache, the group with pneumonia comprised only $46.5 \%$ of patients with headache $(p=0.0001)$. The study included a total of 60 patients with headache in the CCHF group; of these, 23 were females (38.3\%) and 37 were males (61.7\%). Viral pneumonia patients with headache included 12 males (60\%) and 8 (40\%) females. The mean age of CCHF patients was $47.55 \pm 18.80$ years and that of patients with pneumonia was $52.37 \pm 11.19$ years $(p>0.05)$. The most frequent initial symptom patients experienced was fever, which was observed in 38 patients (58.4\%); headache was the second-most common initial symptom in 24 CCHF patients (40.0\%). The mean length of hospitalization was $7.20 \pm 3.48$ days. Most often headaches were throbbing in character and this was reported by $57.4 \%$ of the patients with CCHF. In order of decreasing frequency, the following headache pain descriptions were observed: squeezing, burning, and aching. Headaches were commonly accompanied by nausea and vomiting in $72.5 \%$ and $62.3 \%$ of the CCHF patients, respectively. As a result, it was found that $66.7 \%$ of patients with CCHF and $37.5 \%$ of patients with pneumonia experienced headaches that qualified as migraines according to the International Headache Classification Committee criteria. The characteristics of headache in pneumonia patients were significantly different than those in the group with CCHF and were not migraine-like (Table 1). In addition, the headache scores of patients with pneumonia were significantly lower than CCHF patients. After stratifying CCHF patients

Table 1. Comparison of headache severity scores, headache characteristics, and associated symptoms between patients with CCHF and pneumonia

\begin{tabular}{lcccc}
\hline & CCHF & Pneumonia & Chi $^{2}$ & p \\
\hline Headache scores* & $4.32 \pm 2.54$ & $2.63 \pm 1.23$ & - & 0.004 \\
Throbbing (\%) & 67.4 & 42.5 & 10.81 & 0.005 \\
Nausea (\%) & 72.5 & 37.5 & 15.20 & 0.0001 \\
Vomiting (\%) & 62.3 & 25.4 & 17.58 & 0.0001 \\
Photophobia (\%) & 60.8 & 19.4 & 11.81 & 0.004 \\
Phonophobia (\%) & 62.6 & 49.8 & 8.4 & 0.054 \\
Duration (> 4 h) (\%) & 65.4 & 36.4 & 12.76 & 0.002 \\
Increase with activity (\%) & 51.9 & 35.3 & 6.77 & 0.031 \\
\hline
\end{tabular}

${ }^{*} Z=-2.87$ for headache scores with MannWhitney- $U$ test

CCHF: Crimean-Congo hemorrhagic fever. 
Table 2. Comparisons between CCHF patients in groups 1 and 2 (Group 1: Patients discharged within 7 days, Group 2: Patients hospitalized longer than 7 days)

\begin{tabular}{lccc}
\hline & $\begin{array}{c}\text { Group 1 } \\
\text { (Mean } \pm \text { SD) }\end{array}$ & $\begin{array}{c}\text { Group 2 } \\
\text { (Mean } \pm \text { SD) }\end{array}$ & p \\
\hline Quantity (n) & 33 & 27 & - \\
Age (years) & $47.12 \pm 20.69$ & $47.85 \pm 18.40$ & 0.883 \\
Hospital stay (days) & $5.09 \pm 1.46$ & $9.78 \pm 2.52$ & 0.0001 \\
Platelet level (x1000) & $57.37 \pm 30.11$ & $24.05 \pm 20.62$ & 0.0001 \\
Headache severit score & $3.36 \pm 2.19$ & $5.48 \pm 2.45$ & 0.015
\end{tabular}

Table 3. Comparisons of the age, platelet count and length of hospital stay between CCHF patients with mild and severe headaches

\begin{tabular}{lccc}
\hline & $\begin{array}{c}\text { Mild } \\
\text { headache } \\
(\mathbf{n}=\mathbf{2 6})\end{array}$ & $\begin{array}{c}\text { Severe } \\
\text { headache } \\
(\mathbf{n = 3 4 )}\end{array}$ & $\mathbf{p}$ \\
\hline Age (year) & $48.44 \pm 17.08$ & $46.64 \pm 20.69$ & 0.717 \\
Platelet & $54.54 \pm 35.24$ & $32.42 \pm 23.03$ & 0.005 \\
Hospital stay (days) & $5.85 \pm 2.13$ & $8.30 \pm 3.90$ & 0.004 \\
\hline
\end{tabular}

CCHF: Crimean-Congo hemorrhagic fever.

according to the length of hospital stay, it was found that PLT levels in group1 were significantly higher than those in group 2. In addition, the headache severity scores for group 1 were significantly lower than those for group $2(p<0.05$; Table 2$)$. The length of hospitalization in patients with mild headache pain was shorter than that in patients with severe headache pain. Also, the mean PLT levels in patients with mild headache pain were higher than those in patients with severe headache pain (Table 3 ). There was a significant negative correlation between increasing headache severity and PLT levels $(r=-0.379$, $\mathrm{p}=0.021$ ), whereas a significant positive correlation was identified between increasing headache severity and length of hospital stay $(r=0.385)$. A significant negative correlation was found between the length of hospital stay and PLT levels ( $r=-0.671)$.

\section{Discussion}

Our study is the first to investigate the characteristics of CCHF-induced headaches, which is the secondmost common symptom that we observed in our CCHF patients. The secondary headache observed in patients with systemic infection is well known; however, the headache ratio and severity in CCHF patients was much higher than that in patients with other viral infection. In a recent study of 281 patients hospitalized with CCHF pre-diagnosis, the frequency of certain clinical symptoms, such as fever $(p<0.001)$, headache $(p<0.001)$, widespread body pain, and fatigue in CCHF-positive patients was found to be significantly higher than that in CCHF-negative patients. Therefore, these symptoms along with certain laboratory findings such thrombocytopenia were reported to be highly specific and needed to be considered in the definitive diagnosis of CCHF. ${ }^{[20]}$

Endothelial and immune cells play important roles in CCHF pathogenesis. The CCHF virus either directly impairs endothelial cells or triggers immune cell degranulation, which releases cytokines and indirectly damages endothelial cells. ${ }^{[21,22]}$ Endothelial cells activate when exposed to high levels of proinflammatory cytokines and certain soluble molecules that are upregulated in the setting of infection. Excessive endothelial activation and toxic levels of cytokines may lead to widespread organ failure, shock, and due to increased vascular permeability, vasodilatation, and subsequent hypotension. ${ }^{[1,23,24]}$ Other causative agents of hemorrhagic fever such as the Ebola and Dengue viruses induce an identical proinflammatory response; disease severity is highly correlated with the magnitude of this response. ${ }^{[3,25,26]}$ We determined that CCHF patients having hospital stay $>7$ days and lower PLT levels experience severe headache. These data suggest that the severity of headache is associated with the severity of vascular endothelial damage and abnormal release of inflammatory cytokines in CCHF.

Vascular endothelial dysfunction, vasodilatation, and inflammatory mediators are also involved in the pathogenesis of migraine. ${ }^{[27-29]}$ In animal models, it has been observed that a depolarizing wave propagating across the brain cortex activates the trigeminal nerve. This phenomenon is called a cortical spreading depression (CSD), and it is thought to produce neurological symptoms associated with migraines. ${ }^{[29,30]}$ It has been suggested that CSDs might be initiated by a vascular event, implying that vascular endothelial dysfunction increases susceptibility to migraines. ${ }^{[30]}$ A recent study demonstrated that during migraines there was moderate intracranial 
vessel vasodilatation where headache pain was localized. Furthermore, after the migraine relieved, it was found that vessel vasodilatation also resolved. ${ }^{[31]}$ It appears that endothelial cell injury, vasodilatation, and dysregulated inflammatory mediator release in CCHF causes a similar clinical presentation to migraine headaches, which suggests that cerebral vessel involvement is important in the pathogenesis of both conditions. However, we realized that it is an oversimplification to attribute the mechanism of $\mathrm{CCHF}$ as identical to that of migraines. Likewise, the headache in pneumonia patients was not migrainelike.

\section{Conclusion}

Headache is one of the most common and early clinical manifestations of CCHF. Headache occurrence and severity in CCHF patients were much higher than those in patients with other viral infection. Additionally, the headache severity was associated with the disease severity in our CCHF patients; this data can be used by clinicians as a useful indicator for the course of clinical progress of the disease. These data also suggest that severity of headache is associated with the severity of vascular endothelial damage and abnormal release of inflammatory cytokines in CCHF. The fact that a majority of patients with CCHF also suffer from migraine-like headaches suggests that vascular damage, vasodilatation, and dysregulated cytokine release might play significant roles in the pathogenesis of both migraine and CCHF-induced headache.

\section{Conflict-of-interest issues regarding the authorship or article: None declared.}

\section{Peer-rewiew: Externally peer-reviewed.}

\section{References}

1. Ergönül O. Crimean-Congo haemorrhagic fever. Lancet Infect Dis 2006;6(4):203-14. [CrossRef]

2. Uyar Y, Carhan A, Albayrak N, Altaş AB. Evaluation of PCR and ELISA-IgM results in the laboratory diagnosis of CrimeanCongo haemorrhagic fever cases in 2008 in Turkey. Mikrobiyol Bul 2010;44(1):57-64.

3. Whitehouse CA. Crimean-Congo hemorrhagic fever. Antiviral Res 2004;64(3):145-60. [CrossRef]

4. Sargianou M, Papa A. Epidemiological and behavioral factors associated with Crimean-Congo hemorrhagic fever virus infections in humans. Expert Rev Anti Infect Ther 2013;11(9):897-908. [CrossRef]
5. Morikawa S, Saijo M, Kurane I. Recent progress in molecular biology of Crimean-Congo hemorrhagic fever. Comp Immunol Microbiol Infect Dis 2007;30(5-6):375-89. [CrossRef]

6. Oncü S. Crimean-Congo hemorrhagic fever: an overview. Virol Sin 2013;28(4):193-201. [CrossRef]

7. Ergonul O. Crimean-Congo hemorrhagic fever virus: new outbreaks, new discoveries. Curr Opin Virol 2012;2(2):215-20.

8. Yilmaz GR, Buzgan T, Torunoglu MA, Safran A, Irmak H, Com S, et al. A preliminary report on Crimean-Congo haemorrhagic fever in Turkey, March - June 2008. Euro Surveill 2008;13(33). pii: 18953.

9. Barut S, Dincer F, Sahin I, Ozyurt H, Akkus M, Erkorkmaz U. Increased serum ferritin levels in patients with Crimean-Congo hemorrhagic fever: can it be a new severity criterion? Int J Infect Dis 2010;14(1):e50-4. [CrossRef]

10. Mertens M, Schmidt K, Ozkul A, Groschup MH. The impact of Crimean-Congo hemorrhagic fever virus on public health. Antiviral Res 2013;98(2):248-60. [CrossRef]

11. Swanepoel R, Gill DE, Shepherd AJ, Leman PA, Mynhardt JH, Harvey S. The clinical pathology of Crimean-Congo hemorrhagic fever. Rev Infect Dis 1989;1 1 Suppl 4:S794-800. [CrossRef]

12. Ergonul O. Treatment of Crimean-Congo hemorrhagic fever. Antiviral Res 2008;78(1):125-31. [CrossRef]

13. Koksal I, Yilmaz G, Aksoy F, Erensoy S, Aydin H. The seroprevalance of Crimean-Congo haemorrhagic fever in people living in the same environment with Crimean-Congo haemorrhagic fever patients in an endemic region in Turkey. Epidemiol Infect 2014;142(2):239-45. [CrossRef]

14. Labuda M, Nuttall PA. Tick-borne viruses. Parasitology 2004;129 Suppl:S221-45. [CrossRef]

15. Güneş T. Crimean-Congo Hemorrhagic Fever]. Mikrobiyol Bul 2006;40(3):279-87.

16. Flick R, Whitehouse CA. Crimean-Congo hemorrhagic fever virus. Curr Mol Med 2005;5(8):753-60. [CrossRef]

17. Ozturk B, Tutuncu E, Kuscu F, Gurbuz Y, Sencan I, Tuzun H. Evaluation of factors predictive of the prognosis in CrimeanCongo hemorrhagic fever: new suggestions. Int J Infect Dis 2012;16(2):e89-93. [CrossRef]

18. McCaffery M, Pasero $C$. Teaching patients to use a numerical pain-rating scale. Am J Nurs 1999;99(12):22. [CrossRef]

19. Headache Classification Subcommittee of the International Headache Society. The International Classification of Headache Disorders: 2nd edition. Cephalalgia 2004;24 Suppl 1:9-160.

20. Kilinc C, Gückan R, Capraz M, Varol K, Zengin E, Mengeloglu Z, et al. Examination of the specific clinical symptoms and laboratory findings of Crimean-Congo hemorrhagic fever. J Vector Borne Dis 2016;53(2):162-7.

21. Akıncı E, Bodur H, Leblebicioglu H. Pathogenesis of CrimeanCongo hemorrhagic fever. Vector Borne Zoonotic Dis 2013;13(7):429-37. [CrossRef]

22. Connolly-Andersen AM, Moll G, Andersson C, Akerström S, Karlberg H, Douagi I, et al. Crimean-Congo hemorrhagic fever virus activates endothelial cells. J Virol 2011;85(15):7766-74.

23. Bodur $H$, Akinci $E$, Ongürü $P$, Uyar $Y$, Baştürk $B$, Gözel $M G$, et al. Evidence of vascular endothelial damage in CrimeanCongo hemorrhagic fever. Int J Infect Dis 2010;14(8):e704-7.

24. Chen JP, Cosgriff TM. Hemorrhagic fever virus-induced 
changes in hemostasis and vascular biology. Blood Coagul Fibrinolysis 2000;11(5):461-83. [CrossRef]

25. Schnittler HJ, Feldmann H. Viral hemorrhagic fever-a vascular disease? Thromb Haemost 2003;89(6):967-72.

26. Marty AM, Jahrling PB, Geisbert TW. Viral hemorrhagic fevers. Clin Lab Med 2006;26(2):345-86, viii. [CrossRef]

27. Antonova M, Wienecke T, Olesen J, Ashina M. Prostaglandins in migraine: update. Curr Opin Neurol 2013;26(3):269-75.

28. Olesen J, Burstein R, Ashina M, Tfelt-Hansen P. Origin of pain in migraine: evidence for peripheral sensitisation. Lancet Neurol 2009;8(7):679-90. [CrossRef]
29. Brennan KC, Charles A. An update on the blood vessel in migraine. Curr Opin Neurol 2010;23(3):266-74. [CrossRef]

30. Rubino E, Fenoglio P, Gallone S, Govone F, Vacca A, De Martino $P$, et al. Genetic variants in the NOTCH4 gene influence the clinical features of migraine. J Headache Pain 2013;14:28. [CrossRef]

31. Amin FM, Asghar MS, Hougaard A, Hansen AE, Larsen VA, de Koning PJ, et al. Magnetic resonance angiography of intracranial and extracranial arteries in patients with spontaneous migraine without aura: a cross-sectional study. Lancet Neurol 2013;12(5):454-61. [CrossRef] 